\title{
Comparative studies of religion
}

\author{
U Chai ching Marma
}

\section{Religion in brief is a set of beliefs.}

As it appears in the chambers English dictionary is a belief in recognition of, or an awakened sense of higher unseen controlling power or powers with the emotion and morality connected therewith.

According to Oxford illustrated dictionary religion is the recognition of the superhuman controlling powers. Religion is the teachings appearing in the Tripitaka-sumangala Sinhala dictionary.

It has become a complicated task to define the word religion as both the theistic and the nontheistic teachings are classified under religion. E.B. Tylor in his pioneer study primitive culture defined religion as 'a belief in spiritual beings'. Radcliffe Brown an anthropologist says religion is one form or another of a sense of dependence on a power outs ourselves, a power which we may speak as a spiritual or moral power.

According to Yinger religion is a set of beliefs and practices by means of which a group of people struggles with the ultimate problems of human life. Durkheim understands religion as a unified system of beliefs and practices related to sacred things.

\section{Intellectual definition}

Max Mueller that religion is a mental factor independent of sense and reason to apprehend the infinite in different names.

\section{Psychological definition}

William James said that religion comes from the feelings and experiences and individual people. Religion is the opiate of the masses -Karl Marx. Mircea Eliade says religion is primarily about belief in the supernatural.

According to these definitions, it is clear that religion is not only set a set of beliefs but also a set of rites and rituals connected to those beliefs. Religion can be classified under three major categories.

\section{Primitive religions, 2. Tribal religion and, 3. World religions.}

Primitive religion is a name given to the religious beliefs and practices of those traditional, often isolated, pre-literate cultures which have not developed urban and technologically sophisticated forms of society.

\section{The religion and the philosophy}


Today, religions are classified under two major categories. They are Theistic religions and Non theistic religions. Theistic religions accept the existence of a supreme God while nontheistic religions deny the existence of a supreme God. Judaism, Christianity, Islam and Hinduism are known as theistic religions. Buddhism and Jainism are included in the category of non-theistic religions. Religions can be classified under two major categories.

1. Religions based on rational theology/natural theology.

2. Religions based on revelation theology.

Natural theology/rational theology is the branch of philosophy and theology which attempts to either prove god's existence, define god's attributes, or derive correct doctrine based solely from human reason and/or observations of the natural world. Natural theology holds that knowledge of God can be acquired by human reason without the aid of divine revelation.

Natural theology is the study of God based on the observation of nature, as distinct from "super natural" or revealed theology which is based on special revelation. Because observing nature is an intellectual quest, natural theology involves human philosophy and reasoning as a means of knowing God.

In religion and theology, revelation is the revealing or disclosing of some form of truth or knowledge through supposed communication with a deity or other supernatural entity or entities. In the some theistic religions, the term is used to refer to the process by which God reveals knowledge of himself, his will, and his divine providence, to the world of human beings.

Orthodox Judaism holds that the Torah the first five books of the Old Testament was received from God, and Muslims consider the Quran to have been revealed word by word and letter by letter. In Hinduism some Vedas are considered apauruseya, i.e. "not human compositions", and are supposed to have directly revealed, and thus are called sruti, i.e. "what is heard". Many Christians believe that the Old Testament was inspired by God. But Buddhists believe the three baskets called Tipitaka in Pali which is by the Buddha.

Nevertheless, scholars understand religion as a creation of those human beings who are weak and dependent. It is always the nature of the feeble to seek help from the strong. Religions help the feeble with the influence of external supreme powers to achieve their wishes.

The external supreme power comes into the light with the concept of almighty God. Religions exemplify the relationship between the man and the God. It is a bond similar to father and son or mother and son. For example, In Judaism and Chrisitianity Abba (father). In the Mohenjo Harappa civilization the mother goddess (Jagan Mata).

In addition to the faith and belief of those supreme powers routine of rites and rituals are constantly encouraged in all religions. Teachings of religions are based on hearsay or scriptures; the holy Bible (Both testaments) in Christianity, The holy Bible (the Old Testament) in Judaism, the holy Quran in Islam, and the Veda in Hinduism. 
In all theistic religions there are mediators to keep up the relationship between the god and the man. They are known as priests. These priests are considered as the representatives of the God. In the Vedic tradition priests (Brahmanas) were very much more powerful in the society. They introduced themselves as the gods on the earth. 'Bhu Deva'.

In Judaism there were meditators. They were known as prophets. The word of the God came to the world through the prophets.

Most of these world religions were institutionalized. In Christianity (Roman Catholic Church) there is a high priest. He is called the Pope.

Under the supervision of the Pope there are cardinals, archbishops, bishops, parish priests, fathers, brothers and deacons. There are dedicated to work for the stability of their religion.

Mecca is the Holy center and the religion's headquarters of Muslims. In Islam Ulamas and Maulavis serve as the clergy. They are the mediators who keep up the communication with the God and the man. In early Hinduism Brahmanas were the mediators who served to keep up the link between the man and gods.

Religions expect to have power over their devotees with the enforcement of rites and rituals particular to them. With a view to accomplish the expectations and the needs of their devotees each religion has put up sacred places for worship their gods. Jews got to the Synagogue to worship their god; Christian goes to church; Muslims go to the Mosque and Hindus go to Kovil and the temple to pray to their gods. Buddhist go to the Temple to pay respect to the Buddha shrine.

Each religion has its own sacred symbols. Christianity represents the holy cross, Judaism the five pronged star, an Islam quarter of the moon and a star, Hinduism the Aum, and Buddhism the Dhamma wheel.

Religion has always rejected the scientific knowledge as a means to each the truth. Religions are of the opinion that the philosophy and the right reasoning are harmful to their interests. Religion makes use for fear, sorrow, horror, suspicions, and ignorance to uphold faithfulness of devotees to their principles.

Religion's lend a hand to their devotees to eliminate all sorts of hazards and get the blessings of divine powers for a prosperous future, blessings, support and protection could be obtained through rites and rituals predetermined by each religion. These rites and rituals are executed through mediator priests who are appointed to maintain the correlation between the divine powers and man. Devotees look after the needs of the priests who render their services for them.

Religions in general are conservative and unadventurous. They are much popular among massed and strong enough to revolve their hardships than philosophies. 
Religions fulfill the needs of masses that are not curios about the reality through faith and devotion. Each religion emphasizes the need of a code of morals that should be fulfilled by its followers.

Moral codes are believed to be introduced by the God in heaven. They are beyond questioning. Religions not only accomplish the needs of the ordinary man, but also try to listen to the needs of the wise introducing ways and means for their satisfaction.

Religions make efforts to persuade devotees to follow their fundamental for the sake of atonement. Religions emphasize the supremacy of extra sensory perception than the ordinary sense perception and provide logical arguments to prove the existence of each superhuman power that held the capability of creation sustenance and destruction.

In all religions there are leaders and followers, leaders maintain the stability of the religion and defend their followers from evil forces.

\section{Philosophy is based on rational thinking. It pays attention to every aspect of the world where human awareness is drawn.}

The word philosophy is a combination of two Greek words. Philo and Sophia. In Greek Philo means love Sophia means wisdom. Philosophy is therefore defined as the love of wisdom. The Philosopher is the person who loves wisdom.

According to this definition the aim of philosophy is to inquire about the sustainability of new knowledge and the knowledge already gained. Philosophy always endeavors to find an answer to following questions. What is truth? What is reality? What is knowledge? What is good? What is bad? What is the criterion used to classify the difference between the two etc. etc.

\section{The relationship between the time and space.}

The meanings of relativity are among the questions that philosophy is interested to continue inquires. In the field of philosophy no definite answers will be available for those questions.

There are no leaders in philosophical schools. In the field of philosophy there is no room for blind faith and devotion. Therefore nobody accepts the view of others without reasoning. Each philosopher is free to express his own views. There are no boundaries or prohibitions, nobody is forced to accept others views. Philosophy is always opened for criticism. Philosophical paradigms are not considered as ultimate. Philomels respect each other's views, although they hold different ideologies.

Buddhism cannot be classified either as a religion or a philosophy. It is more like a raft that helps to the opposite shore. Buddhism instructs to eradicate suffering. 
Buddhism is of the view that the ultimate bliss cannot be achieved neither with the help of sensual desires (raamisa) nor free from sensual desires (niraamisa).

According to Buddhism the ultimate bliss can be achieved only through the purification of mind. Buddhist teachings emphasize that everyone should wipe out ignorance (avijja) in the effort to realize the truth. The path that leads to realization is elaborated in the teachings of Buddha.

The life without the understanding of nature of the world unites man into the Samsara, the cycle of births. The freedom is the total extinction of re-becoming.

Nibbana the ultimate reality is not a distant goal that should be obtained in the life span. It can be obtained within this life through proper practice of the noble eight-fold path.

\section{In what form does God exist?}

God is a "personal" being. God is not human yet He is "person" like a man in that He has intelligence, emotions and will (see "communicable attributes"). It is in this sense that we are in the "image of God" (Gen. 1:26,27; 9:6). He does not share our imperfections, but he does share our personal nature. God is not a "force". He is a personal being.

God is a "spiritual" being. God does not consist of any material substance. He is spirit (John 4:24). He has no body. God is a "truinity". "trinity" is a term that describes the "threeness" of God. But that is only a partial description. God is also "one" -He is a unified being. So a good term to describe both thrust is "Truinity." "Trinity" may always be the most - used term, but we must understand that biblically "Trinity" is really "Truinity".

In Hinduism the Vedic tradition the concept of Brahman is a combination of three gods; Indra (creator), Varuna (protector) and Prajapati (destroyer).

The origin of the concept of Trinity begins with the earliest writings of men. Records of early Mesapotanian, Mediterianean and Indian civilizations show polytheistic religions. On the other hand the idea of one god existed in the same thought.

The historian S.H. Hooke clarifies the ancient Sumerian trinity. ANU was the primary god of heaven, the father the king of gods. ENIL the wind God, the God of the earth. And ENKI the God of waters and the Lord of wisdom.

H.W.F. sages explains that the Babylonian triad consisted of three gods whose interrelationship is of the essence of their nature.

Those were not only trinities early Christians were exposed to. It is clear that the Christian trinity may have influenced by those cultures and also by the Roman culture.

In contrast Judaism is strongly monotheistic with no hint of the trinity. The Hebrew Bible conforms 'Before me there was no god formed. Neither shall any be after me. (Isa. 43.10) 
Scholars argue that the concept of trinity did not originate from Judaism nor did Jesus speak of a trinity. The message of Jesus was the coming kingdom was a message of love and forgiveness. "I seek not mine with own will, but the will of the father which had sent me. (John 5.30)

"My doctrine is not mine, but His that sent me. (John 7.16)

Nowhere in the bible the concept of trinity is mentioned or discussed, but there are mentions about the father son and the spirit in the bible. The "threeness" of God. Each of the 3 persons possesses what only God has, so each is fully God. The father is God. (Rom. 1:7) - "God (who is) our Father"

To all that be in Rome, beloved of God, called to be saints: Grace to you and peace from God our father, and the Lord Jesus Christ. (King James Version (KJV)

Do not work for food that spoils, but for food that endures to eternal life, which the son of Man will give you. For on him God the Father has placed his seal of approval." (John 6:27) "the Father (even) God". I came from the father and have come into the world again. I am leaving the world and going to the Father. (John 6:28)

But now, O Lord, thou art our Father; we are the clay, and thou our potter; and we all are the work of thy hand. (Isaiah 64.8 (KJV)

Without father, without mother, without descent, having neither beginning of days, nor end of life; but made like unto the son of God; abide a priest continually.

(John 10.38) but if I do, though ye believe not me, believe the works: that ye may know, and believe, that the father is in me, and I in him.

Jesus saith unto him, have I been so long time with you, and yet hast thou not known me, Philip? He that hath seen me hath seen the Father; and how sayest thou then, show us the Father?

The son is the radiance of god's glory and the exact representation of his being. When we speak of Jesus, we speak of the same god who created heaven and earth and manifested himself in the person of Christ $1^{\text {st }}$ Timothy 3.16

\section{Holy spirit}

These are the things God has revealed to us by his spirit. The spirit searches all things, even the deep things of God. 1 Corinthians 2:10

Now the Lord is the spirit, and where the spirit of the Lord is, there is freedom and we all, who with unveiled faces contemplate the Lord's glory, are being transformed into his image with ever-increasing glory, which comes from the Lord, who is the spirit. 2 Corinthians 3:1718 
Those who live according to the flesh have their minds set on what the flesh desires; but those who live in accordance with the spirit have their minds set on what the spirit desires. Romans 8:5

According to scholars the concept of trinity appeared in the biblical literature more than 100 years after the crucifixion. Trinity was not an explicit doctrine of the New Testament. This may have evolved after the $4^{\text {th }}$ century.

If the concept of trinity did not originate with the bible where did it come from? To find the origins one has to look at the circumstances in which early Christians found themselves.

The evolution of the concept of trinity can be well seen in the words of apostle's creed and the Athenian's (Greek) creed.

The father is God. The son is God and the Holy Spirit is god and yet they are not three but one god. In this trinity of persons the son is created by the father by an eternal generation and the Holy Spirit proceeds by an eternal procession from the father and the son. The Greek Church did not neglect to safeguard the doctrine of the divine unity. Greek fathers regarded the son as the wisdom and power of the father ( $1^{\text {st }}$ corr. 1.24.) the spirit is his sanctity. Thus the son and the spirit are termed as the power of the father.

\section{The "oneness" of God}

There is only one God (Deut. 6:4; Is. 45:14: James 2:19, etc.) - there can only be one perfect being. If there were two they would not differ at all and would thus be the same being.

The one god is not divisible into parts - since God is spirit of nature and not material in composition, he cannot be divided into 3 parts of 1/3 God each. God the father, God the son or God the Holy Spirit therefore cannot be conceived of any anything less than wholly God in essence.

\section{Buddhism}

Buddhism is not a god centered teaching. It is a human centered teaching. Buddhism does not accept the idea of divine creation. The Buddha is not the creator of the universe and also neither the sustainer or the destructor of the universe. The Buddha is fully a human being. He was born as a human being, reached the enlightenment as a human being and demised as a human being.

Even though the personality of the Buddha is described with paranormal powers such as thirty two major signs and eighty minor signs it is easy to find enough evidences to prove his human characteristics.

As it appears in the cannon the Buddha suffered from a back pain "Pitthim me agilayati tamaham ayamissami." In the Maha Gosingasala Sutta of the M.N., it is said the Buddha was not permitted to enter the Gosingasala mango park by the gate keeper as he misunderstood the Buddha as an ordinary hermit. 
Examples that illustrate the human nature of the Buddha appear in the Ariya Pariyesana Sutta and the Dhatu vibhanga sutta of M.N., and in the Maha Parinibbana sutta of the D.N.

The Buddha is not the savior, but the teacher (satta) who pointed out the correct path for emancipation of human beings and super human beings. (Tumhehi Kiccam atappam akkhataro eve tathagato aha) Maha Parinibbana suta D.N.

In Buddhism freedom from suffering has to be realized individually. No one is able to save a person from suffering. Even the Buddha could not help Ven. Ananda to reach the Arahantship before his demise. The Buddha only encouraged Ven. Ananda to strive hard to reach the ultimate goal.

Suffering is the foremost truth common to all beings. (Dukkha) Dukkha suggests a basic unsatisfactoriness pervading all forms of life, due to the fact that all forms of life are impermanent and constantly changing. Dukkha indicates a lack of satisfaction, a sense that things never measure up to our expectations or standards. The Buddha comprehended the truth of the origin of Dukkha. The origin (Pali: samudaya) of Dukkha is commonly explained as craving (tanha) conditioned by ignorance (avijja) this craving runs on three channels. Craving for sense-pleasures (kama tanha), this is craving for sense objects which provide pleasant feeling, or craving for sensory pleasures.

Craving to be (bhava tanha): this is craving to be something, to unite with an experience. This includes craving to be solid and ongoing, to be a being that has a past and a future, and craving to prevail and dominate over others. Craving not to be (vibhava tanha): this is craving to not experience the world, and to be nothing; a wish to be separated from painful feelings.

The third Noble truth is the truth of the cessation of Dukkha. Cessation (Pali: nirodha) refers to the cessation of suffering and the causes of suffering. It is the cessation of all the unsatisfactory experiences and their causes in such a way that their final absence, the cessation of those things their non-arising."

Cessation is the goal of one's spiritual practice in the Buddhist tradition. According to the Buddhist point of view, once a person has developed a genuine understanding of the causes of suffering, such as craving (tanha) and ignorance (avijja), and then he can completely eradicate these causes and thus be free from suffering.

The fourth noble truth is the path to the cessation of Dukkha. This path is called the noble eightfold path, and it is considered to be the essence of Buddhist practice. The eightfold path consists of: Right Understanding, (samma ditthi), right thought (samma samkappa), right speech (samma Vaca), right action (samma kammanta), right livelihood (samma Ajiva), right effort (samma Vayama), right mindfulness (samma sati) and right concentration (samma Samadhi).

In the path of purification one should understand the true nature of the secular life. The knowledge of reality of the world leads the person to disgust. Firstly person enjoys the world 
(assada) secondly he understands unsatisfactoriness of everything in the secular world (adinava). Thirdly he leaves everything behind him and lives without any attachment (nissarana).

This leads to dispassionateness, in other words absence of desire (viragaya). As a result of dispassionateness the influx of defilements are annihilated (nirodha). With the annihilation of the influx of defilements all defilements that exist in the mind of the individual disappear (Upasamaya).

This leads to the higher knowledge (Abhinnaya). Higher knowledge paves way to enlightenment (sambodaya) and finally reaches the total extinction (Nibbanaya).

\section{Buddhist and Christian attitude towards law}

A code of law is established with a view to maintain order, peace and harmony in the society. Laws are rules of a community or a state. (Chambers English Dictionary) law is defined in the Oxford illustrated Dictionary p.463 as a body of enacted or customary rules recognized by a community as a binding.

At the beginning there was neither a code of ethics nor any other common system of behavior established at the beginning of the society. There existed only the law of the jungle. Before laws are introduced to keep peace and harmony in the early civilized human society, there was a code of moral that maintained the peace and harmony.

In the law of the jungle the feeble animals always became the victims of powerful animals. Where the law of the jungle existed in the human society the power enjoyed all rights and benefits while the weak suffered. In the law of the jungle what the power does is considered as the just.

The Agganna sutta of the D.N., clarifies how the powerful members of the society enjoyed natural resources and stored them for the future leading the weak to suffer. As a result of this unruly behavior of the powerful others assembled against them. Pragmatism means dealing with things sensibly and realistically in a way that is based on practical rather than theoretical considerations.

The Buddhist laws lay down penalties or punishments for each specific type of offences. The philosophy behind these penalties was based on full-fledged compassion. According to Buddhist vinaya a wrong- doer is a person who is misdirected either by himself or others. The case of Angulimala is a good example. Angulimala was a robber.

He was fierce, with bloody hands, engaged in killing living things without mercy. At that time he destroyed complete villages, complete hamlets and even the state. He killed humans to wear a garland of fingers. It was possible for a person such as Angulimala to enter the order of monks and became an Arahant. "he who formerly was slothful, but afterwards is diligent illumines the world like the moon freed a cloud. He whose evil done kamma is closed by what is skilled illumines the world" MN vol 2 Angulimala sutta. 
Buddhist vinaya laws are always flexible and established on a democratic foundation. The Buddha always paid attention to the public opinion.

At that time the Blessed One dwelt at Rajagaha, in the Veluvana, in the Kalandaka Nivapa. At that time the retreat during the rainy season had not yet been instituted by the blessed one for the Bhikkhus. Thus the Bhikkhus went on their travels alike during winter, summer, and the rainy season.

People were annoyed, murmured, and became angry, saying, 'How can the Sakyaputtiya Samanas go on their travels alike during winter, summer, and the rainy season? They crush the green herbs, they hurt vegetable life, and they destroy the life of many small living things. Shall the ascetics who belong to Titthiya schools, whose doctrine is ill preached, retire during the rainy season and arrange places for them to live in?

Shall the birds make their nests on the summits of the trees, and retire during (p. 299) the rainy season, and arrange themselves places to live in; and yet the Sakyaputtiya Samanas go on their travels alike during winter, summer, and the rainy season, crushing the green herbs, hurting vegetable life, and destroying the life of many small things?' Buddha advised his disciples to accept if the words of people are acceptable and meaningful.

Natural law is the idea that there is an objective moral order based in essential humanity that holds universal and permanent suggestions for the ways we should conduct ourselves as free and responsible beings. Natural law/lex naturalis/natural justice/jus natural.

The founder of the modern theory of natural law was Jonathan Althusius - 1557. He was of the opinion that there can be only one and that an indivisible sovereignty. Only as in one body there is only a single soul. The sovereignty can only reside in one place and can neither be transferred nor alienated.

Natural law theories, then, propose to identify principles of right action-moral principlesspecifying the first and most general principle of morality, namely, that one should choose and act in ways that are compatible with a will towards fundamental human fulfillment. Among these principles is a respect for rights people possess simply by virtue of their humanity-rights which, as a matter of justice, others are bound to respect and governments are bound not only to respect but, to the extent possible, also to protect.

This natural law understanding of human rights is connected with a particular account of human dignity. Under this account, the natural human capacities for reason and freedom are fundamental to the dignity of human beings-the dignity that is protected by human rights. The basic goods of human nature are the goods of a rational creature - a creature that, unless weakened or prevented from doing so, naturally develops and exercises capacities for consideration, judgment, and choice.

It is a theory that some laws are basic and fundamental to human nature and are discoverable by human reason without reference to specific legislative enactments or judicial decisions. 
Natural law is opposed to human law which is human made, conditioned by the history and subject to continuous change.

Natural law theories have profoundly influenced the development of English law. Natural law, according to Hobbes is a precept. A Man is forbidden to do that which is destructive of his life. The first law of nature appearing in Leviathan is "Every man ought to endeavor peace, as far as he has hope of obtaining it and when he could not obtain it he may seek and use all helps and advantages of war.

Divine law is initiated by the God to govern his creations and kingdoms and to prescribe behavior of his children. In the Middle Ages law was considered to have been dictated by divine will and revealed to wise man.

Divine law is a perfect system comprehended through faith and reason. The belief in the divinity of law implies partly that there is an unseen and supreme power that originated the law. This law is divine because its source is divine. The Ten Commandments are considered as the words of God.

In Islamic theory, God is the Sovereign of the community of believers; he is its ultimate ruler and legislator. The revelation and divine wisdom are the primary sources of the developing public order, presuming to meet the community's growing needs and expectations. The principles and maxims of justice derived from the revelation and divine wisdom were considered infallible and inviolable, designed for all-time and potentially capable of application to all men. In principle, the law laid down by the divine legislator is an ideal and perfect system.

\section{Conclusion}

The above short description regarding the differences of religious teachings would value to our study field of diversity of religious teachings. Every religions teaching based on goodness to be a respectable person in the society. We need religion to understand the nature life in deepest. The above description has included the set of beliefs, philosophical views, the belief and the existence of God and the law in the religious teachings. 